\title{
Structural Equation Modeling in Research on Brand Capital in Higher Education
}

\author{
Casanoves-Boix, Javier ${ }^{a}$; Küster-Boluda, Inés ${ }^{b}$ and Vila-López, Natalia ${ }^{c}$ \\ ${ }^{a}$ Department of Marketing, ESIC Business and Marketing School, Spain, ${ }^{b}$ Department of \\ Marketing, Universitat de València, Spain, ${ }^{c}$ Department of Marketing, Universitat de \\ València, Spain.
}

\begin{abstract}
This research is done in order to examine the role of the brand capital in higher education. For this purpose, we analyze the main contributions of the literature related to the study of the brand capital and its application in the educational sector, identifying which variables determine the brand capital in the higher education sector. Once we establish the susceptible brand capital in the higher education sector, an empirical research is done by using a questionnaire developed in Spanish language with a Likert scale of grade 5 in which 1 point means "strongly disagree" and 5 mean "strongly agree", being based on the measurement scales proposed by Aaker (1992) and Keller (1993). Thus, we have a valid sample of 690 university professors (438 of them from public institutions and 356 from private ones). The results have been obtained by using a structural equation method, showing the relevance of each variable and determining those most discriminant for university professors.
\end{abstract}

Keywords: Brand Capital, Brand Equity, Higher Education, Structural Equation Method, University Professors 


\section{Introduction}

Brands have evolved into a life experience for consumers, acquiring an emotional importance to them, that is reflected in their purchase satisfaction (Camacho, 2008). However, in the search for new forms of differentiation involving the actual creation of customer value, companies must be economically efficient (Kuster, and Aldás Vila, 2011). In the context discussed, brands can play an important role in the educational sector because in the last years universities have integrated marketing strategies and policies in its business model, both private and public (Fernández, 2002). So, there are some evidences that confirm that the marketing's theories and concepts can be applied in the educational context and, especially, in the field of higher education (Küster, 2012).

However, and as it is pointed out by the authors, the literature in this area is incoherent, still incipient, with a lack of theoretical models that reflect the particular context and the nature of the services of higher education. Because of that, in this research we contemplate two objectives, such as: (1) to analyze what it is understood as brand capital and what are its variables and determining components, talking about its application in the education sector; (2) to analyze what are the most relevant and discriminator elements of brand capital of the Higher Education Institutions, from the professors point of view.

In the same way, the elaboration of this research may be helpful for the university managers, given that they can figure out the key points in the opinions of several employees, with respect to the brand capital of their institutions and then to produce suitable strategies in order to maintain or improve the brand capital. So, with the purpose of reaching the objectives described above, we are dividing this research into two large parts: (1) review of the scientific literature regarding to our field of study, the brand capital and its key elements, as well as the exhaustive analysis of the marketing inside the education sector in Spain and (2) empirical research with university professors from Spanish universities, with the goal of decode those variables of the brand capital are more discriminator by using a structural equation method.

\section{A brand capital model applied to higher education}

After having revised the 7 main proposals about brand capital models done by literature and several contributions in the field of higher education, we present in Table 1 those elements shared by the authors in their models, whose cross elements have been considered key for our investigation, keeping in mind the importance of previous studies. Thus, all the authors consider four elements that, even though they are named in different ways, we understand that they have the same importance for the brand capital. These elements are: (1) brand awareness, (2) brand image, (3) perceived quality and (4) brand loyalty. These contributions, and more done by the literature, allow us to establish the following hypothesis, showed in Figure 1.

H1: The perception of brand awareness influences in the perception of brand capital among university professors.

$\mathrm{H} 2$ : The perception of brand image influences in the perception of brand capital among university professors. 
H3: The perception of perceived quality influences in the perception of brand capital among university professors.

H4: The perception of brand loyaly influences in the perception of brand capital among university professors.

Table 1. Main elements of brand capital in higher education

\begin{tabular}{|c|c|c|c|c|c|c|c|c|}
\hline \multirow[b]{2}{*}{$\begin{array}{l}\text { Elements of } \\
\text { Brand Capital }\end{array}$} & \multicolumn{7}{|c|}{ Tot Brand Capital Models } & \multirow[b]{2}{*}{ Proposals of Brand Capital in Higher Education } \\
\hline & $\begin{array}{l}\text { Farquhar } \\
\text { (1989) }\end{array}$ & $\begin{array}{l}\text { Aaker } \\
(1992)\end{array}$ & $\begin{array}{l}\text { Keller } \\
(1993)\end{array}$ & \begin{tabular}{|c|} 
Faircloth, \\
Capella y \\
Alford (2001)
\end{tabular} & $\begin{array}{l}\text { Yoo y } \\
\text { Donthu } \\
\text { (2001) }\end{array}$ & $\begin{array}{l}\text { Delgado y } \\
\text { Munuera } \\
(2002)\end{array}$ & $\begin{array}{l}\text { Buil, Martínez y } \\
\text { De Chernatony } \\
\text { (2010) }\end{array}$ & \\
\hline BRAND AWARENESS & & $\mathrm{x}$ & $\mathrm{x}$ & & $x$ & $x$ & $\mathrm{x}$ & BRAND AWARENESS \\
\hline Brand Recall & & & $\bar{x}$ & & & & & \multirow{4}{*}{$\begin{array}{c}\text { Koku, 1997; Morphew, 2001; Sevier, 2001; Toma, Dubrow } \\
\text { y Hartley, 2005; Brunzel, 2007; Furey, Springer y Parsons, } \\
\text { 2009; Brewer y Zhao, 2010; Pinar, Trapp, Girard y Boyt, } \\
2014\end{array}$} \\
\hline Brand Recognition & & & $x$ & & & & & \\
\hline Brand Prominence & & & $x$ & & & & & \\
\hline Perceived Risk Reduction & & $x$ & & & & & & \\
\hline BRAND IMAGE & $\mathrm{x}$ & $x$ & $\mathrm{x}$ & $\mathrm{x}$ & $\mathrm{x}$ & $x$ & $\mathrm{x}$ & \multirow{8}{*}{$\begin{array}{c}\text { BRAND IMAGE } \\
\text { Smith y Ennew, 2000; Bosch, Venter, Han y Boshoff, 2006; } \\
\text { Jevons, 2006; Hamann, Williams y Omar, 2007; Hemsley- } \\
\text { Brown y Goonawardana, 2007; Chen, 2008; Denegri, } \\
\text { Cabezas, Herrera, Páez y Vargas, 2009; Williams y Omar, } \\
\text { 2009; Waeraas y Solbakk, 2009; Whisman, 2009; Gómezy } \\
\text { Medina, 2010; Stripling, 2010; Mourad, Ennew y Kortam, } \\
\text { 2011; Williams, Williams, y Omar, 2013; Pinar, Trapp, } \\
\text { Girard y Boyt, 2014 }\end{array}$} \\
\hline Brand as a Company & & $x$ & & & & & & \\
\hline Brand Associations & $\mathrm{x}$ & & $\mathrm{x}$ & $\mathrm{X}$ & $\mathrm{X}$ & & $\mathrm{X}$ & \\
\hline Brand Differentiation & & $x$ & & & & & & \\
\hline Brand Imagination & & & $\mathrm{x}$ & & & & & \\
\hline Brand Performance & & & $\mathrm{x}$ & & & & & \\
\hline Brand Personality & & $\mathrm{x}$ & & & & & & \\
\hline Brand Reputation & & $x$ & & & & $x$ & & \\
\hline PERCEIVED QUALITY & & $\mathrm{x}$ & $x$ & & $x$ & $x$ & $\mathrm{x}$ & PERCEIVED QUALITY \\
\hline Brand Esteem & & $x$ & & & & & & \multirow{8}{*}{$\begin{array}{c}\text { Kissman y Van Tran, 1990; Ramsden, 1991; Byron, 1995; } \\
\text { Athiyaman, 1997; Vorhies, 1997; Booth, 1999; Binsardi y } \\
\text { Ekwulugo, 2003; Mai, 2005; Peltier, Schibrowsky y Drago, } \\
\text { 2007; Chen, 2008; Billings, Engelberg, Curtis, Block y } \\
\text { Sullivan, 2010; Mourad, Ennew y Kortam, 2011; Pinar, } \\
\text { Trapp, Girard y Boyt, } 2014\end{array}$} \\
\hline Brand Feelings & & & $\mathrm{X}$ & & & & & \\
\hline Brand Judgements & & & $\mathrm{x}$ & & & & & \\
\hline Brand Leadership & & $x$ & & & & & & \\
\hline Brand Popularity & & $\mathrm{x}$ & & & & & & \\
\hline Brand Reviews & & & $\mathrm{x}$ & & & & & \\
\hline Perceived Value & & $x$ & & & & & & \\
\hline Willingness to Pay More & & & $x$ & & & & & \\
\hline BRAND LOYALTY & $x$ & $x$ & & & $x$ & $x$ & $x$ & BRAND LOYALTY \\
\hline Brand Resonance & & & $\mathrm{x}$ & & & & & \multirow{5}{*}{$\begin{array}{c}\text { Nicholls, Harris, Morgan, Clarke y Sims, 1995; Nguyen y } \\
\text { LeBlanc, 2001; Lerman y Garbarino, 2002; Helgesen, } \\
\text { 2008; Bok, 2009; Brown y Mazzarol, 2009; Pawsan y } \\
\text { Ganesh, 2009; Rojas, Vasquez, Kara y Cerdá, 2009; Pinar, } \\
\text { Trapp, Girard y Boyt, 2014 }\end{array}$} \\
\hline Brand Trust & & $x$ & & & & & & \\
\hline Customer Appreciation & & $\mathrm{x}$ & & & & & & \\
\hline Customer Satisfaction & $\mathrm{x}$ & $\mathrm{x}$ & & & & & & \\
\hline Price Premium & & $\mathrm{X}$ & & & & & & \\
\hline
\end{tabular}

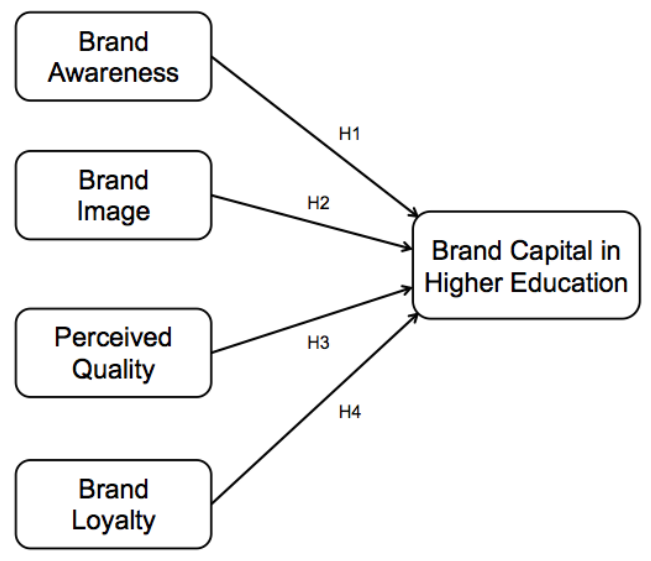

Figure 1. Theoretical model proposed for this research 


\section{Methodology}

In order to corroborate the established hypothesis, we accomplished an empirical research quantitative in nature, by means of a survey in Spanish aimed at a group of 438 professors from the Faculty of Economics from two public universities, and at a group of 356 from six private ones in Valencia (Spain), obtaining an amount of 690 useful surveys for our investigation.

If we base on Churchill (1979) recommendations, and in the measuring scale suggested by Aaker (1992) and Keller (1993), we can detect four segments of measurement, which are: (1) brand awareness, (2) brand image, (3) perceived quality and (4) brand loyalty. All of them have been measured with the Likert scale of grade 5 (Bozal, 2005).

The technics for the data analysis are based on the Descriptive Statistics and the Multivariate Analysis, using as a support tool the SPSS v.18 for Windows for the data descriptive techniques and the EQS 6.2 for implementing the multivariate techniques. The statistical processing followed in this research for the data implies the implementation of analysis methods dependent on the information we need to obtain, making a difference between: (1) data description and classification, and (2) hypothesis testing.

\section{Results}

On one hand, the scales were measured by using a confirmatory factor analysis, where all loads and t robust values were significant at $p<0.01$ value. The reliability was checked by three methods of analysis. First, using the Cronbach Alpha (CA) and obtaining values higher than 0.70 in all cases, which helped us to accept this rule (Nunnally and Bernstein, 1994). Second, doing an analysis of composite reliability (CR) and also obtaining values higher than 0.70 (Carmines and Zeller, 1979). Finally, in order to determine the reliability, we also did an analysis of the average variance extracted (AVE), where the results were close or above to 0.50 (Fornell and Larcker, 1981). 
Table 2. Reliability and convergent validity of the scales

\begin{tabular}{|c|c|c|c|c|c|c|}
\hline FACTOR & INDICATOR & LOAD & $t$ ROBUST & $\mathrm{CA}$ & CR & AVE \\
\hline \multirow{5}{*}{$\begin{array}{c}\text { Brand } \\
\text { Awareness }\end{array}$} & BA1 & $0.52^{\star \star \star}$ & 6.23 & \multirow{5}{*}{0.85} & \multirow{5}{*}{0.86} & \multirow{5}{*}{0.56} \\
\hline & BA2 & $0.81^{\star \star \star}$ & 10.78 & & & \\
\hline & BA3 & $0.84^{\star * *}$ & 9.99 & & & \\
\hline & BA4 & $0.82^{\star \star \star}$ & 10.98 & & & \\
\hline & BA5 & $0.70^{\star \star \star}$ & 8.66 & & & \\
\hline \multirow{11}{*}{ Brand Loyalty } & $\mathrm{Bl} 1$ & $0.63^{\star \star *}$ & 7.26 & \multirow{11}{*}{0.91} & \multirow{11}{*}{0.91} & \multirow{11}{*}{0.48} \\
\hline & $\mathrm{BI} 2$ & $0.77^{\star \star \star \star}$ & 9.31 & & & \\
\hline & $\mathrm{BI} 3$ & $0.87^{\star \star \star}$ & 13.91 & & & \\
\hline & $\mathrm{Bl} 4$ & $0.75^{\star * \star}$ & 12.24 & & & \\
\hline & BI5 & $0.57^{* \star \star \star}$ & 7.14 & & & \\
\hline & $\mathrm{BI} 6$ & $0.75^{\star \star \star}$ & 11.92 & & & \\
\hline & $\mathrm{BI} 7$ & $0.61^{\star \star \star}$ & 8.10 & & & \\
\hline & $\mathrm{B} 18$ & $0.41^{\star \star \star}$ & 4.59 & & & \\
\hline & BI9 & $0.67^{* \star *}$ & 8.71 & & & \\
\hline & $\mathrm{Bl} 10$ & $0.77^{\star \star \star}$ & 12.11 & & & \\
\hline & $\mathrm{Bl} 11$ & $0.69^{\star * \star}$ & 8.22 & & & \\
\hline \multirow{21}{*}{$\begin{array}{c}\text { Perceived } \\
\text { Quality }\end{array}$} & PQ1 & $0.77^{\star \star \star}$ & 9.09 & \multirow{21}{*}{0.95} & \multirow{21}{*}{0.95} & \multirow{21}{*}{0.48} \\
\hline & PQ2 & $0.62^{\star \star \star}$ & 9.79 & & & \\
\hline & PQ3 & $0.80^{\star \star *}$ & 12.74 & & & \\
\hline & PQ4 & $0.84^{\star \star \star}$ & 12.34 & & & \\
\hline & PQ5 & $0.69^{\star \star \star *}$ & 9.31 & & & \\
\hline & PQ6 & $0.51^{\star \star *}$ & 5.70 & & & \\
\hline & PQ7 & $0.63^{\star \star \star}$ & 8.35 & & & \\
\hline & PQ8 & $0.74^{\star \star \star}$ & 10.70 & & & \\
\hline & PQ9 & $0.61^{\star \star \star}$ & 8.75 & & & \\
\hline & PQ10 & $0.48^{\star \star \star *}$ & 5.61 & & & \\
\hline & PQ11 & $0.60^{\star \star \star}$ & 8.04 & & & \\
\hline & PQ12 & $0.70^{\star \star *}$ & 9.58 & & & \\
\hline & PQ13 & $0.84^{* \star *}$ & 11.94 & & & \\
\hline & PQ14 & $0.73^{\star \star \star}$ & 11.47 & & & \\
\hline & PQ15 & $0.63^{\star \star \star}$ & 8.05 & & & \\
\hline & PQ16 & $0.55^{\star \star \star}$ & 6.77 & & & \\
\hline & PQ17 & $0.65^{\star \star \star}$ & 9.66 & & & \\
\hline & PQ18 & $0.79^{\star \star \star}$ & 12.96 & & & \\
\hline & PQ19 & $0.65^{\star \star \star}$ & 9.27 & & & \\
\hline & PQ20 & $0.80^{\star \star \star}$ & 10.70 & & & \\
\hline & PQ21 & $0.71^{\star \star \star}$ & 8.08 & & & \\
\hline \multirow{11}{*}{ Brand Loyalty } & BL1 & $0.82^{\star \star \star *}$ & 11.85 & \multirow{11}{*}{0.95} & \multirow{11}{*}{0.94} & \multirow{11}{*}{0.60} \\
\hline & BL2 & $0.87^{\star \star \star}$ & 13.34 & & & \\
\hline & BL3 & $0.80^{\star \star \star}$ & 13.80 & & & \\
\hline & BL4 & $0.86^{\star \star \star}$ & 13.59 & & & \\
\hline & BL5 & $0.86^{\star \star \star}$ & 15.86 & & & \\
\hline & BL6 & $0.63^{\star \star \star *}$ & 8.60 & & & \\
\hline & BL7 & $0.82^{\star \star \star \star}$ & 11.43 & & & \\
\hline & BL8 & $0.50^{\star \star \star}$ & 6.08 & & & \\
\hline & BL9 & $0.80^{\star \star \star *}$ & 12.50 & & & \\
\hline & BL10 & $0.81^{\star \star \star \star}$ & 12.32 & & & \\
\hline & BL11 & $0.63^{\star \star \star}$ & 9.67 & & & \\
\hline \multirow{4}{*}{ Brand Capital } & $\mathrm{BC} 1$ & $0.41^{\star \star \star}$ & 4.55 & \multirow{4}{*}{0.76} & \multirow{4}{*}{0.74} & \\
\hline & $\mathrm{BC} 2$ & $0.71^{\star \star \star}$ & 8.32 & & & 043 \\
\hline & BC3 & $0.85^{\star \star \star}$ & 12.79 & & & 0.43 \\
\hline & BC4 & $0.59^{\star \star \star}$ & 6.65 & & & \\
\hline
\end{tabular}

On the other hand, the results suggest that the model designed in this research applied to the professors staff is satisfactory to explain the four hypotheses, obtaining a significant effect in the brand capital model proposed. Moreover, the goodness of fit statistics suggest that the structural model fits well with the data structure $(\mathrm{S}-\mathrm{B} \chi 2(\mathrm{p})=5.407,353(0,0000), \mathrm{df}=$ 1.263; NFI $=0,78$; NNFI $=0,81 ; \mathrm{CFI}=0,82 ; \mathrm{IFI}=0,82 ; \mathrm{RMSEA}=0,07)$. Moreover, we can observe in the Table 3 that the university professors give more importance to the perceived quality, followed by the brnd loyalty, the brand image and, finally, the brand awareness. 
Table 3. Validation of the proposed model

\begin{tabular}{|c|l|c|c|c|}
\hline Hypothesis & \multicolumn{1}{|c|}{ Structural Relationship } & $\boldsymbol{\beta}$ Estand. & t Robust & Result \\
\hline H1 & $\begin{array}{l}\text { Perception of Brand Awareness --> } \\
\text { Perception of Brand Capital }\end{array}$ & $0,065^{\star \star \star}$ & 3,37 & Accepted \\
\hline H2 & $\begin{array}{l}\text { Perception of Brand Image --> } \\
\text { Perception of Brand Capital }\end{array}$ & $0,114^{\star \star \star}$ & 4,14 & Accepted \\
\hline H3 & $\begin{array}{l}\text { Perception of Perceived Quality --> } \\
\text { Perception of Brand Capital }\end{array}$ & $0,545^{\star \star \star}$ & 7,49 & Accepted \\
\hline H4 & $\begin{array}{l}\text { Perception of Brand Loyaly --> } \\
\text { Perception of Brand Capital }\end{array}$ & $0,337^{\star \star \star}$ & 6,37 & Accepted \\
\hline
\end{tabular}

$\mathrm{N}=690 ;{ }^{* \star *} \mathrm{p}<0,01 ;{ }^{* *} \mathrm{p}<0,05 ;{ }^{*} \mathrm{p}<0,1$

Satorra-Bentler $\chi^{2}(p)=5.407,35(0.0000), d f=1.263 ; \mathrm{NFI}=0,78 ; \mathrm{NNFI}=0,82 ; \mathrm{CFI}=0,82 ; \mathrm{IFI}=0,82 ; \mathrm{RMSEA}=0,07$

\section{Conclusions}

Firstly, the profile indicates that the sample is a mixed group of men and women from public and private university (very heterogeneous sample), 40 years middle age, with responses from 9 different nationalities (Spain is the country with the highest number of responses). Moreover, there are an average of 10 years work experience, being the majority of the sample full-time workers with an average monthly salary from 2,000 and 3,000 euros (considering that over $60 \%$ of staff is studying a $\mathrm{PhD}$ program).

On the other hand, and observing the results of hypothesis test, we can observe that the overall model proposed show a positive and direct relationship for the 4 hypotheses. So, there is a positive relationship between perceptions of brand awareness, brand image, perceived quality, brand loyalty and brand capital

\section{References}

Aaker, D. A. (1992). The value of brand equity. Journal of business strategy, 13(4), 27-32.

Athiyaman, A. (1997). Linking student satisfaction and service quality perceptions: the case of university education. European Journal of Marketing, 31(7), 528-540.

Bok, D. (2003). Universities in the marketplace: The commercialization of higher education. Princeton University Press.

Bozal, M.G. (2005): Escala mixta Likert-Thurstone. Anduli: revista andaluza de ciencias sociales, (5), 81-96.

Bosch, J., Venter, E., Han, Y., \& Boshoff, C. (2006). The impact of brand identity on the perceived brand image of a merged higher education institution: Part one. Management Dynamics: Journal of the Southern African Institute for Management Scientists, 15(2), 10-30.

Brewer, A., \& Zhao, J. (2010). The impact of a pathway college on reputation and brand awareness for its affiliated university in Sydney. International Journal of Educational Management, 24(1), 34-47.

Brown, R.M., \& Mazzarol, T.W. (2009). The importance of institutional image to student satisfaction and loyalty within higher education. Higher Education, 58(1), 81-95. 
Brunzel, D.L. (2007): Universities sell their brands, Journal of Product \& Brand Management, 16(2), 152-3.

Buil, I., Martínez, E., \& De Chernatony, L. (2010). Medición del valor de marca desde un enfoque formativo.

Camacho, J. (2008). El valor de la marca: Brand Equity. Datos, Diagnóstico y Tendencias. Nielsen. http://mx.nielsen.com/press.

Carmines, E. G., \& Zeller, R. A. (1979). Reliability and validity assessment. Vol. 17. Sage publications.

Chen, L.H. (2008). Internationalization or international marketing? Two frameworks for understanding international students' choice of Canadian universities, Journal of Marketing for Higher Education, 18(1), 1-33.

Churchill, G.A. (1979). A Paradigm for Developing Better Measures of Marketing Constructs. Journal of Marketing Research. 16(1), 64-73.

Delgado-Ballester, E. \& Munuera, J.L. (2002). Medición del capital de marca con indicadores formativos. Investigación y Markerting, 759, 16-20.

Denegri, M., Etchebarne, M.S., Geldres, V., Cabezas, D., \& Herrera, V. (2009). Personalidad de marca de las carreras de ciencias empresariales: un análisis corporativo entre universidad pública y privada.

Faircloth, J.B., Capella, L.M., \& Alford, B.L. (2001). The effect of brand attitude and brand image on brand equity. Journal of Marketing Theory and Practice, 61-75.

Farquhar, P.H. (1989). Managing brand equity. Marketing research, 1(3).

Fernández, C. (2002). Introducción al marketing para centros de enseñanza. ESIC Editorial, 2002.

Fornell, C., \& Larcker, D. F. (1981). Structural equation models with unobservable variables and measurement error: Algebra and statistics. Journal of marketing research, pp. 382-388.

Furey, S., Springer, P. \& Parsons, C. (2009). University Brand Promises, Presentation at Academy of Marketing 2009 Conference.

Gómez, D.F.H., \& Medina, R.Z. (2010). Diagnóstico de la imagen de marca de las instituciones universitarias en España.

Hamann, D., Williams, R., \& Omar, M. (2007). Branding Strategy and Consumer HighTechnology Product, The Journal of Product \& Brand Management, 16, (Winter/Spring), 2, 98-111.

Hemsley-Brown, J. \& Goonawardana, S. (2007). Brand harmonization on the international higher education. Journal of Business Research, 60(9), 942-948.

Jevons, C. (2006). Universities: a prime example of branding gone wrong, Journal of Product \& Brand Management, 15(7), 466-447.

Keller, K.L. (1993). Conceptualizing, measuring, and managing customer-based Brand equity, Journal of Marketing, 57, 1-22.

Kissman, K., \& Van Tran, T. (1990). Perceived quality of field placement education among graduate social work students. Journal of Continuing Social Work Education, 5(2), 27 30 . 
Koku, P. (1997). What Is in a Name? The Impact of Strategic Name Change on Student Enrollment in Colleges and Universities, Journal of Marketing for Higher Education, $8(2), 53-71$.

Küster, I., Vila, N., \& Aldás, J. (2011). Brand Equity Innovation: el uso de las nuevas tecnologías en el sector del vino para el incremento del valor de marca. Distribución y Consumo, 116, 67.

Küster, I. (2012). El Docente Universitario desde una perspectiva de mercado: Influencia en el rendimiento del estudiante. Alicante: 3 ciencias, 1-118.

Lerman, D. \& Garbarino, E. (2002). Recall and Recognition of Brand Names: A Comparison of Word and Nonword Name Types, Psychology \& Marketing, 19 (7/8), 621.

Morphew, C. (2001). A Rose by Any Other Name? Which Colleges Become Universities, The Review of Higher Education, 25 (2).

Mourad, M., Ennew, C., \& Kortam, W. (2011). Brand equity in higher education.Marketing Intelligence \& Planning, 29(4), 403-420.

Nunnally, J. C., \& Bernstein, I. H. (1994). Psychometric theory. Third Edition. McGrawHill. New York.

Paswan, A.K., \& Ganesh, G. (2009). Higher education institutions: Satisfaction and loyalty among international students. Journal of Marketing for Higher Education, 19(1), 65-84.

Peltier, J.W., Schibrowsky, J.A., \& Drago, W. (2007). The interdependence of the factors influencing the perceived quality of the online learning experience: A causal model. Journal of Marketing Education, 29(2), 140-153.

Pinar, M., Trapp, P., Girard, T., \& Boyt, A. T. (2014). University Brand Equity: An Empirical Investigation of its Dimensions, Staying Current with Media \& Millennials, 50.

Rojas-Méndez, J.I., Vasquez-Parraga, A.Z., Kara, A.L.I., \& Cerda-Urrutia, A. (2009). Determinants of student loyalty in higher education: A tested relationship approach in Latin America. Latin American Business Review, 10(1), 21-39.

Smith, R. \& Ennew, C. (2000). Service quality and its impact on word of mouth communication in higher education, paper presented at the Academy of Marketing Annual Conference, University of Derby, Derby, 5-7 July.

Stripling, J. (2010). Brand new dilemma, available at: http://insidehighered.com/news/2010/10/ 19/branding (accessed June 27, 2013).

Toma, J.D., Dubrow, G., \& Hartley, M. (2005). The uses of institutional culture: Strengthening identification and building brand equity in higher education. Wiley Periodicals, Inc.

Waeraas, A., \& Solbakk, M. (2009): Defining the essence of a university: lessons from higher education branding, Higher Education, 57(4), 449-462.

Whisman, R. (2009). Internal branding: a university's most valuable intangible asset. Journal of Product \& Brand Management, 18(5), 367-370.

Williams, R.L., \& Omar, M. (2009). Renaming Service Organizations for Growth, Presentation at Academy of Marketing 5th International Colloquium: Brand, Identity and Corporate Reputation, University of Cambridge, U.K. 
Williams, R.L., Williams, H.A., \& Omar, M. (2013). The Marketing Impact of the Principles of Renaming Within a Higher Education Service Organization, American Marketing Association.

Yoo, B., \& Donthu, N. (2001). Developing and validating a multidimensional consumerbased brand equity scale. Journal of business research, 52(1), 1-14. 